\title{
The Analysis of the Moderating Effects of Tourism Attraction on the Correlation of Travel Constraints and Revisit Intention
}

\author{
Case Study: Tourist of Bromo Tengger Semeru National Park
}

\author{
Devi Destiani Andilas \\ Tourism and Leisure Management \\ Petra Christian University \\ Surabaya, Indonesia \\ devi.destiani@petra.ac.id
}

\author{
Febry Ristanto \\ Tourism and Leisure Management \\ Petra Christian University \\ Surabaya, Indonesia \\ febryristanto@gmail.com
}

\begin{abstract}
Some factors might hinder a person to travel, but tourism attraction is predicted to be a factor that can motivate tourists to solve their obstacles then decide to revisit the destination. Nowadays, the revisit frequency of both domestic and international tourists becomes an important aspect for Indonesia in order to achieve the 2020 national tourism targets which are 20 million foreign tourists and 375 million domestic trips. The purpose of this study is; first, to investigate the moderating effects of tourism attraction on the negative impact of travel constraints on tourists' revisit intention. Second, this study provides tourism destination management an insight for developing a strategy to increase the tourists' revisit intention. The data were collected through a questionnaire from 50 domestic tourists who had visited Bromo Tengger Semeru National Park, then analyzed using simple and multiple linear regressions. The findings reveal that travel constraints negatively influence tourists' revisit intention and tourist attraction is a pure moderator that weaken the influence between travel constraints and revisit intention. The intention to revisit a destination decreases when the constraints (e.g. distance, limited time, lack of money. and information) increase. Fortunately, a variety of activities, uniqueness, and the beauty of tourism attractions encourage the tourists to overcome the constraints which eventually push their intention to revisit the destination.
\end{abstract}

Keywords - travel constraint, revisit intention, tourism attraction

\section{INTRODUCTION}

$\underline{\text { Research Background }}$

Tourism is one of the four dimensions in the leading sector development stated in the National Medium Term Development Plan (NMTDP) of 2014-2019 Jokowi-JK governance period. In the last period of Jokowi-JK governance, 2019, tourism is targeted to be able to contribute $8 \%$ to the Gross Domestic Product per capita (GDP) or income per capita compared to the previous 2014 GDP which only contributed to 4\%. The contribution is obtained from foreign tourists as many as 20 million visits and local tourist of 270 million visits. In order to achieve the target, tourists are expected to visit various tourist destinations in Indonesia or revisit the destinations which have been a favorite. Nowadays, the government focuses on management development of 10 tourist destinations to become "a new Bali" which has a strong magnet to attract tourists. The 10 tourism destinations are Toba Lake (North Sumatera), Tanjung Kelayang (Bangka Belitung), Tanjung Lesung (Banten), Thousand Islands (DKI Jakarta), Borobudur Temple (Central Java), Bromo Tengger Semeru National Park (TNBTS -East Java), Mandalika (Lombok, West Nusa Tenggara), Labuan Bajo (Flores, East Nusa Tenggara), Wakatobi (Sulawesi Tenggara), and Morotai (Moluccas).

A place can be called a tourism destination when it consists of four dimensions namely attractions, accessibilities, amenities, and ancillary services [1]. As aforementioned, nowadays government (as the realization of ancillary services) focuses on tourism in 10 leading destinations. However, it needs to be remembered that management development of tourism destination related to the infrastructure development (accessibility and facilities), activities to "beautify" the destination or to incorporate variations of tourist attractions cannot merely make someone to decide to travel. This is possible since the decision to travel is one of the complex decision makings, influenced by many factors such as individual's internal conditions including health, financial ability, time availability, while external conditions including accessibility to the tourist destination, the security of tourist destination, and also the previous experiences or others' experiences as the references as visualized in Fig.1 as in [2]. There are three dimensions of individuals' constraints in conducting the travel (travel constraints) as in [3], namely (1) structural constraint such as lacking of time, money, information related to the tourism destination, access limitation, and weather condition; (2) intrapersonal constraints such as lack of interest; (3) interpersonal constraint such as no friends/ families in the travelling trips that will be carried out. 
This has been proven on TNBTS, as one of the 10 priorities of development, Bromo tourism has undergone improvement/arrangement, development of activity variations, but it still cannot guarantee the tourism revisits. Thirty-three local people who have visited TNBTS, we inquired about their revisit intention and it was obtained that only $40 \%$ of the people who have the revisit intention. Therefore, this research was conducted with aims to find out whether travel constraints influence the tourist to have a revisit intention. In addition, whether the tourist attraction can weaken the existing constraints so that the intention to revisit increases. By conducting this research, it is expected that the constraints can be handled well by the related parties (such as marketer and destination management organization). Eventually, it can enhance the tourists' intention to revisit in which later will impact on the increase in the number of tourists in order to achieve the predetermined tourism target.

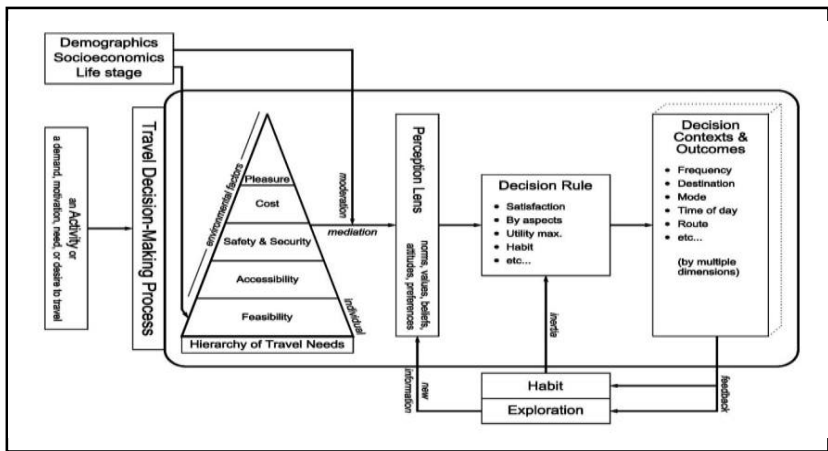

Fig 1. Conceptual Framework of the Travel Decision-Making Theory

\section{Literature review}

This research refers to the three studies related to travel constraints. First, research entitled "a multilevel analysis of the effects of wine destination attributes on travel constraints and revisit intention" [4], aimed at investigating whether the attributes of tourist destinations can increase the negative effects of travel constraint on the intention to revisit. After obtaining the answer, the researchers could help the tourist destination to develop its marketing strategy. In the research, there are three subvariables from travel constraints and six sub-variable of destination attributes. The three sub-variable of travel constraints are structural constraints related to distance, time, and money. The interpersonal constraint related to the existence of travel mates or supports from other family members, and interpersonal constraint related to selfmotivation, psychological condition, and the limited information. The six sub-variable of destination attributes namely competitive environment (environmental competitiveness), global environment (global economy condition, politics stability, government regulations, and socio-demography), core resources and attractors (nature's view, weather, culture, accommodation, restaurant, transportation, etc.), supporting factors and resources (infrastructure, amenities, access), destination management (tourist destination regulations, reputation planning and development, and the strengthening of destination image), and qualifying determinants (location, destination, cost, and security). The research results showed that a negative impact of structural travel constraint causing the low revisit intention can be weakened if the tourists have an emotional interest on a destination. Moreover, the negative impact of interpersonal travel constraint causing the low revisit intention can be weakened if the infrastructure condition in the tourist destination is good and a positive perception of tourist destination can be established.

The second research as a reference entitled how motivations, constraints, and demographic factors predict seniors' overseas travel propensity" [5]. The study aimed at finding out the influence of travel motivation, travel constraint, and demography variable on elderly tourists traveling abroad. The results showed that age, income, employment status, motivation related to relaxation, motivation related to finding something new, motivation of socializing and personal constraints related to emotions and health become the main factor influencing the tendency of elderly tourist to travel abroad. The motivation related to relaxation and finding something new affect positively on matters related to socialization and interaction with external as well as health influences negatively.

The third research entitled "understanding travel constraint: application and extension of a leisure constraints model" [6] revealed that there are three dimensions of travel constraints they are structural, interpersonal, and intrapersonal. Intrapersonal dimension related to the lack of interest, stress, depression, worries, religiousness, relatives, and self-skills. Interpersonal dimension related to not having travel mate, family or couple to join in doing the travel. The structural dimension related to the lack of time, money, and tourist destination attributes (such as the availability of information, access-distance, and weather condition) the research results showed the sequence of constraints as follows, time is the main constraint, followed by cost, interpersonal constraint, tourist destination attributes, and intrapersonal constraint as the weakest constraint influencing the travel decision.

Based on the literature review from several previous studies, the researchers hypothesized that:

H1. Travel constraints impact negatively on the tourists' revisit intention to TNBTS

H2. TNBTS' tourism attraction weakens the travel constraints on the tourists' revisit intention to TNBTS 


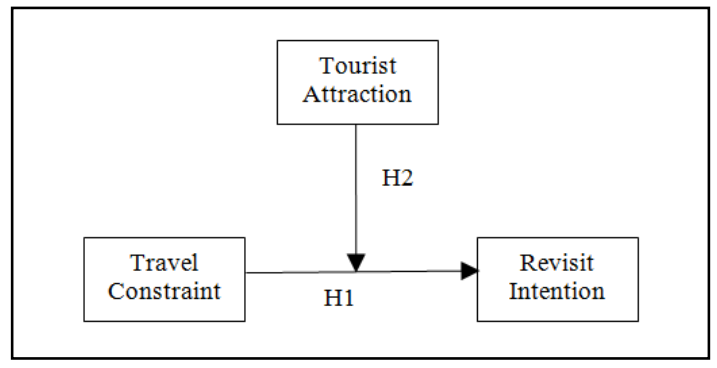

Fig 2. Research conceptual model

\section{Methodology}

This research is a descriptive research with a quantitative method. The researchers collected the data through a questionnaire with a Likert scale of 1-5 which represented the degree of respondents' agreement from strongly disagree to strongly agree. The questionnaire was distributed to 50 domestic tourists aged above 18 years old who have visited TNBTS in the past one year. The collected data were then analyzed using a regression model path analysis technique. A simple linear regression model was used to test the influence between travel constraint and the interest of revisit variables. As well as, a multiple linear regression model was utilized to test the moderator of tourism attraction on the influence of travel constraints on the revisit intention. The path analysis with regression model was used since the researchers focused on investigating the correlation between variables, this is in accordance as in [7] that "path analysis is a technique to analyze the cause and impact relationship occurred on multiple regressions if the independent variable influences the dependent variable not only directly but also indirectly". The minimum of sample size in this research caused the researchers to use SPSS software as the analysis tool.

In this research, there are three variables as presented in the research model in Fig 2, namely travel constraint as the independent variable $(\mathrm{X})$, tourism attraction as the moderator variable $(\mathrm{Z})$, and revisit intention as the dependent variable (Y). Specifically, on Variable $\mathrm{X}$, the researchers limited the travel constraints on time, money, and tourist destination attributes (weather, cleanliness, and the crowdedness in the tourist destination).

\section{RESULT}

Respondents' Profiles

The data in Table I show that from 50 respondents there were 28 males $(56 \%)$ and 22 females $(44 \%)$. The respondents aged ranging from 18-25 years old were 33 people (66\%), 26-40 years old 7 were people (14\%), 4155 years old were 9 people $(18 \%)$ and above 55 years old was 1 person (2\%). Respondents originated from several different cities, such as there were 23 people from Surabaya (46\%), 14 people from Malang (28\%), 3 people from Probolinggo (6\%), 8 people from Sidoarjo (16\%) and 4 people from other cities. The respondents' background of education also varied there were 29 people (58\%) graduates, 12 people are high school students( $24 \%$ ), and 9 people are graduates from other than the two educational background (18\%). Most of the respondents were still students, as many as 23 people (46\%), besides students there are also 12 people as employees (22\%), 12 people as entrepreneurs (24\%), and respondents with other occupations were 4 people (8\%).

Besides the demography profile, in Table 1 , it can be seen the travel pattern trip of respondents. Mostly, the respondents visit TNBTS with friends 31 respondents (62\%), with family 17 respondents (34\%), and solo traveling 2 respondents (4\%). In TNBTS, the respondents who spent their time less than 12 hours were 21 respondents (42\%), 1 night were 24 respondents (48\%) and more than 1 night were 5 respondents (10\%). The number of respondents' expenditure to travel to TNBTS was varied, 5 respondents (10\%) spent less than 100 thousand Rupiahs, 23 respondents (46\%) spent 100 to 250 thousand Rupiahs, 15 respondents (30\%) spent 250 to 500 thousand Rupiahs, and 7 respondents spend more than 500 thousand Rupiahs.

\section{Hypothesis Testing}

The first hypothesis was tested using a simple linear regression model as in (1), where travel constraints (X) as the independent variable and revisit intention to TNBTS $(\mathrm{Y})$ as the dependent variable. The regression equation formed is as follows:

$$
Y=12.497-0.167 X
$$

In Table II, the regression coefficient of travel constraints valued -0.167 and the $t$-significance value was 0.000 . The value of the negative coefficient showed that there is a non-mutual correlation between travel constraints and revisit intention to TNBTS. If there is no travel constraint $(X=0)$, then the tourists have the revisit intention to TNBTS as much as 12.497 , but if the tourists have travel constraints of 1 unit, then the tourists' revisit intention to TNBTS decreases as much as 0.167. The significance value was $0.000<0.05$, then it can be concluded that $\mathrm{H} 1$ was accepted: travel constraints impact negatively on the tourists' revisit intention to TNBTS.

TABLE I. DESCRIPTION OF SAMPLE

\begin{tabular}{|c|c|c|c|}
\hline \multicolumn{2}{|r|}{$\mathbf{N}=\mathbf{5 0}$} & Frequency & $\%$ \\
\hline \multirow{3}{*}{ 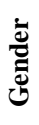 } & Men & 28 & 56 \\
\hline & Women & 22 & 44 \\
\hline & Total & 50 & 100 \\
\hline \multirow{5}{*}{$\sum_{4}^{8}$} & $18-25$ & 33 & 66 \\
\hline & $26-40$ & 7 & 14 \\
\hline & $41-55$ & 9 & 18 \\
\hline & $>55$ & 1 & 2 \\
\hline & Total & 50 & 100 \\
\hline \multirow{3}{*}{ 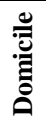 } & Surabaya & 23 & 46 \\
\hline & Malang & 14 & 28 \\
\hline & Probolinggo & 3 & 6 \\
\hline
\end{tabular}




\begin{tabular}{|c|c|c|c|}
\hline & Sidoarjo & 8 & 16 \\
\hline & Others & 2 & 4 \\
\hline & Total & 50 & 100 \\
\hline \multirow{4}{*}{ 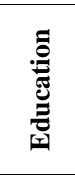 } & Bachelor & 29 & 58 \\
\hline & High School & 12 & 24 \\
\hline & Others & 9 & 18 \\
\hline & Total & 50 & 100 \\
\hline \multirow{5}{*}{ 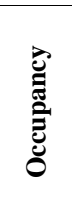 } & Employee & 11 & 22 \\
\hline & Student & 23 & 46 \\
\hline & Entrepreneur & 12 & 24 \\
\hline & Others & 4 & 8 \\
\hline & Total & 50 & 100 \\
\hline \multirow{4}{*}{ 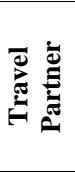 } & Friends & 31 & 62 \\
\hline & Family & 17 & 34 \\
\hline & Alone & 2 & 4 \\
\hline & Total & 50 & 100 \\
\hline \multirow{4}{*}{ 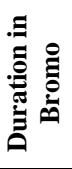 } & $<12$ Hour & 21 & 42 \\
\hline & 1 Night & 24 & 48 \\
\hline & $>1 \mathrm{Night}$ & 5 & 10 \\
\hline & Total & 50 & 100 \\
\hline \multirow{5}{*}{ 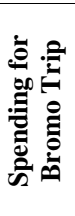 } & $<100 \mathrm{k}$ IDR & 5 & 10 \\
\hline & 100k - 250k IDR & 23 & 46 \\
\hline & 250k - 500k IDR & 15 & 30 \\
\hline & $>500 \mathrm{k}$ IDR & 7 & 14 \\
\hline & Total & 50 & 100 \\
\hline
\end{tabular}

TABLE II. THE SIGNIFICANCE OF SIMPLE LINEAR REGRESSION TVALUE

\begin{tabular}{|c|c|c|c|c|}
\hline \multirow{2}{*}{} & \multicolumn{2}{|c|}{$\begin{array}{c}\text { Unstandardized } \\
\text { Coefficients }\end{array}$} & \multirow{2}{*}{$\mathrm{T}$} & \multirow{2}{*}{ Sig } \\
\cline { 2 - 3 } & $\mathrm{B}$ & Std. Error & & \\
\hline (constant) & 12.497 & 1.040 & 12.020 & 0.000 \\
\hline $\mathrm{X}$ & -0.167 & 0.033 & -5.088 & 0.000 \\
\hline
\end{tabular}

The second hypothesis was tested by using a multiple linear regressions model as in (2), where travel constraints (X) as the independent variable, tourism attraction $(\mathrm{Z})$ as the moderator variable, and revisit intention to TNBTS (Y) as the dependent variable. The regression equation formed as follows:

$$
Y=18.032-0.496 X-0.190 Z+0.11 X^{*} Z
$$

In Table IV, it can be found out that the F-value was calculated $17.157>$ from the F-value in Table 2.81 with the significant value of $0.000<0.05$, thus it can be concluded that $\mathrm{H} 2$ was accepted: the TNBTS tourism attraction weakened the influence of travel constraints on the tourists' revisit intention to TNBTS. Based on Table $\mathrm{V}$ as in [8], the tourism attraction variable acted as a pure moderator variable. This is reflected from the significance results of T-value (Table III), where the coefficient of $b_{2}$ (Z) the significance value was $0.269>0.05$; nonsignificant, while the coefficient of $b_{3}\left(X^{*} \mathrm{Z}\right)$ its significance value was $0.027<0.05$; significant.
TABLE III THE SIGNIFICANCE OF MULTIPLE LINEAR REGRESSION T-VALUE

\begin{tabular}{|c|c|c|c|c|}
\hline \multirow{2}{*}{} & \multicolumn{2}{|c|}{$\begin{array}{c}\text { Unstandardized } \\
\text { Coefficients }\end{array}$} & \multirow{2}{*}{$\mathrm{t}$} & Sig \\
\cline { 2 - 3 } & $\mathrm{B}$ & Std. Error & & \\
\hline (constant) & 18.032 & 6.604 & 2.730 & 0.009 \\
\hline $\mathrm{X}$ & -0.496 & 0.180 & -2.764 & 0.008 \\
\hline $\mathrm{Z}$ & -0.19 & 0.170 & -1.120 & 0.269 \\
\hline $\mathrm{X} * \mathrm{Z}$ & 0.011 & 0.005 & 2.280 & 0.027 \\
\hline
\end{tabular}

TABLE IV. THE SIGNIFICANCE OF MULTIPLE LINEAR REGRESSION F-VALUE

\begin{tabular}{|c|c|c|c|c|c|}
\hline & $\begin{array}{c}\text { Sum of } \\
\text { squares }\end{array}$ & df & $\begin{array}{c}\text { mean } \\
\text { square }\end{array}$ & F & Sig \\
\hline Regression & 166.95 & 3 & 55.65 & 17.157 & 0.000 \\
\hline Residual & 149.23 & 46 & 3.244 & & \\
\hline Total & 316.18 & 49 & & & \\
\hline
\end{tabular}

TABLE V. THE CLASSIFICATION OF MODERATOR VARIABLE

\begin{tabular}{|c|l|c|l|}
\hline No & Types of Moderators & \multicolumn{2}{|c|}{ Coefficient } \\
\hline \multirow{2}{*}{1} & \multirow{2}{*}{ Pure Moderator } & $\mathrm{b}_{2}$ & non-significant \\
\cline { 3 - 4 } & & $\mathrm{b}_{3}$ & significant \\
\hline \multirow{2}{*}{2} & \multirow{2}{*}{ Pseudo Moderator } & $\mathrm{b}_{2}$ & significant \\
\cline { 3 - 4 } & & $\mathrm{b}_{3}$ & significant \\
\hline \multirow{2}{*}{3} & \multirow{2}{*}{ Predictor Moderator } & $\mathrm{b}_{2}$ & non-significant \\
\cline { 3 - 4 } & & $\mathrm{b}_{3}$ & non-significant \\
\hline \multirow{2}{*}{4} & \multirow{2}{*}{ Potential Moderator } & $\mathrm{b}_{2}$ & significant \\
\cline { 3 - 4 } & & $\mathrm{b}_{3}$ & non-significant \\
\hline
\end{tabular}

In Table VI, the value of Adjusted R square $\left(\mathrm{R}^{2}\right)$ was 0.497 meaning that $49.7 \%$ the level variations of revisit intention to TNBTS can be explained by the travel constraint variable $(\mathrm{X})$ and the tourism attraction $(\mathrm{Z})$. The rest as much as $51.3 \%$ is explained by other causes which are not observed, such as the factors of amenity availability, socio-political conditions in the tourist destination, physical/health conditions of the tourist, and others.

TABLE VI. THE COEFFICIENT OF DETERMINATION OF MULTIPLE LINEAR REGRESSION

\begin{tabular}{|c|c|c|c|}
\hline $\mathrm{R}$ & $\begin{array}{c}\mathrm{R} \\
\text { Square }\end{array}$ & $\begin{array}{c}\text { Adjusted } \mathrm{R} \\
\text { Square }\end{array}$ & $\begin{array}{c}\text { Std. Error of } \\
\text { the Estimate }\end{array}$ \\
\hline $0.727^{\mathrm{a}}$ & 0.528 & 0.497 & 1.80115 \\
\hline
\end{tabular}

\section{CONCLUSION AND DISCUSSION}

The results of this research showed that there are negative influences on the tourists' revisit intention to TNBTS. The greater the constraints such as the limitation of money, time, and the latest information related to the tourist place conditions, the smaller the intentions of the tourists to revisit. However, the condition can be minimized when the TNBTS offers various attractions 
such as nature's beauty as well as diverse activities that can be done.

The TNBTS tourist destination has been managed since 1982. The domestic tourists of TNBTS originated from several cities around the destination (Table 1) with the distance ranging between 30 to $120 \mathrm{~km}$ and the travel duration ranging between 30 minutes 3 hours. the cost needed to travel to TNBTS is 250,000-500,000/person on average. The sacrifice of time and money, added with the weather condition (the overly cold temperature) oftentimes becomes the constraint for the tourists to revisit. However, the tourists will willingly sacrifice more if there are interesting things offered by TNBTS destination. In the era of 1990 s, the tourists only offered by the beauty of the sunrise in Bromo Mountain, the offroad sensation riding jeep cars, as well as the activities of horseback riding around the sea of sand. In the 2000s, the managers of TNBTS opened the access to savanna known as "Teletubbies hill" and offered the activities of ÄTV riding". In 2009, some musicians initiated the event of "Jazz Gunung/ Mountain Jazz", a show of jazz music with the background of Bromo Mountain view, the high enthusiasm of people to watch the event making the "Mountain Jazz" as the annual agenda in TNBTS. The past two years, in order to realize the government's target as mentioned in the background, the managers of TNBTS held "Festival Eksotika Bromo/ Bromo Exotica Festival"; a cultural festival of Tengger tribe festival, the Indigenous people of Bromo Mountain.

The beauty of Bromo Mountain will keep making the tourists revisit, but the revisit will occur in a long time span after the first travel due to the experienced constraints by the tourists. Therefore, the addition of types of activities and the event organizing was administered by the managers as part of the development of the tourist attraction of TNBTS to increase the tourists' revisit intention. "Events have a long-term effect in the context of destination marketing because they have the ability to generate repeat visits" as in [9]. The more new things available for the tourists, the more sacrifice made by the tourists to handle the constraints more to do revisit.

\section{REFERENCES}

[1] C. Cooper, J. Fletcher, D. Gilbert and S. Wanhill, "Tourism: Principles and practice" 1993, Harlow: Longman.

[2] P. A. Singleton, "The Theory of Travel Decision-Making: A Conceptual Framework of Active Travel Behavior," TREC Friday Seminar Series, 2015, Retrived from https://pdxscholar.library.pdx.edu/trec_seminar/84 on 24th january 2017.

[3] D. W. Crawford, E. L. Jackson, and G. Geoffrey, "A Hierarchical model of leisure constraints." Journal Leisure Sciences, 1991, vol. 13, pp. 309-320.

[4] M. A. Boon, M. Cho, J. J. Lee, and J. H. Kim, "A multilevel analysis of the effects of wine destination attributes on travel constraints and revisit intention," International Journal of Contemporary Hospitality Management, 2016, vol. 28, pp. 23992421

[5] C. F. Chen and C. C. Wu, "How Motivations, Constraints, and Demographic Factors Predict Seniors 'Overseas Travel Propensity." Asia Pacific Management Review, 2009, vol. 14, pp. 301-312.

[6] G. P. Nyaupane and K. L. Andereck, "Understanding Travel Constraints: Application and Extension of a Leisure Constraints Model," Journal of Travel Research, 2008, vol. 46, pp. 433-439.

[7] R. D. Retherford and K. C. Minja, "Statistical models for casual analysis," 1993, John Wiley \& Sons: New York.

[8] Solimun, “Analisis Variabel Moderasi dan Mediasi," Program Studi Statistika FMIPA Universitas Brawijaya Malang, 2017, Retrived from http://management.feb.umy.ac.id/labmanajemen/wpcontent/uploads/2017/04/Materi-Moderasi-Solimun.pdf on 07th March 2017

[9] A. Kuusik, K. Nilbeb, T. Mehinea and R. Ahasb, "Country as a free sample: the ability of tourism events to generate repeat visits: case study with mobile positioning data in Estonia." Procedia Social and Behavioral Sciences, 2014, vol. 148, pp. 262-270. 